Pirjo Lyytikäinen, Vesa Haapala, Anna Hollsten, Jyrki Nummi, Riikka Rossi ja Juhani Sipilä

\title{
Helsingin Kotimainen kirjallisuus: Perinteitä ja uusia haasteita
}

Kotimaisen kirjallisuuden oppiaine Helsingin yliopistossa on saanut alkunsa Werner Söderhjelmiä varten vuonna 1913 perustetusta kotimaisen ja yleisen kirjallisuushistorian professorin virasta. Se jaettiin kahtia vuonna 1924, jolloin suomenkielisen professuurin sai Viljo Tarkiainen ja ruotsinkielisen Gunnar Castrén. Kun yleinen kirjallisuus ja kotimainen erkanivat vuonna 1968, syntyi kotimaisen kirjallisuuden laitos, joka ehti toimia itsenäisenä tasan 30 vuotta. Nykyään kotimainen kirjallisuus kuuluu oppiaineena suureen suomen kielen, suomalaisugrilaisten ja pohjoismaisten kielten ja kirjallisuuksien laitokseen, jota leikillisesti myös Norsuksi kutsutaan.

Oppiaineessa on kaksi professoria, Pirjo Lyytikäinen ja Jyrki Nummi, sekä kolme yliopistonlehtoria, Juhani Sipilä, Anna Hollsten ja Vesa Haapala. Amanuenssia ei kevään 2016 jälkeen enää ole. Yliopistouudistus on kuitenkin jälleen mullistamassa oppiaineen asemaa: syksystä 2017 alkaen oppiaine on opintosuunta Kotimaisten kielten ja kirjallisuuksien kandiohjelmassa ja Kirjallisuudentutkimuksen maisteriohjelmassa. Itse opetus ja tutkimus säilyvät kuitenkin näiden koulutusohjelmien alla.

Helsingin kotimaisen kirjallisuuden opinnoissa tähdätään laaja-alaiseen kaunokirjallisuuden tuntemiseen ja teorian inspiroimiin analyysitaitoihin. Maistereita valmistuu vuosittain enemmän kuin sisään otetaan uusia opiskelijoita (sisäänotto oli pitkään 16, mutta tiedekunta on höylännyt sitä alaspäin). Tutkimuksen painopistealueisiin on kuulunut jo pitkään lyriikan tutkimus ja modernismin eri vaiheet varhaisesta modernismista postmodernismiin. Nykykirjallisuudestakin on tehty väitöskirjoja ja muuta tutkimusta varsin vilkkaasti. Myös realismin, naturalismin ja ylipäätään lajien tutkimus ovat olleet oppiaineen vahvoja alueita, samoin intertekstuaalisuus eri muodoissaan. Väitöskirjoja on viime aikoina valmistunut vuosittain $2-3$, ja niitä on kirjoitettu suomeksi, ruotsiksi, englanniksi ja ranskaksi.

Opettajien tutkimustoiminta on ollut laaja-alaista. Lyytikäinen on tutkinut klassikkoja, Volter Kilpeä, Aleksis Kiveä ja Leena Krohnia sekä erikoistunut symbolismin ja dekadenssin tutkimukseen. Hänen nykyisissä tutkimusintresseissään päällimmäisenä on kirjallisuuden ja tunteiden tutkimus. Nummi on tutkinut Linnaa, Ahoa ja Kiveä, viime vuosina erityisesti Kiven draamaa. Nykyiset tutkimusaiheet liittyvät Seitsemän veljeksen kriittisen edition laatimiseen sekä kaanonien ja klassikkoinstituution tutki- 
mukseen. Haapala on tutkinut modernistista runoutta ja lyhytproosaa (Kivestä, Ahosta ja Södergranista Hyryyn ja Saarikoskeen) sekä nykykirjallisuutta. Hänen nykyisissä tutkimusintresseissään keskeisimpänä on kokoelmakokonaisuuksien poetiikka. Hollsten on tutkinut suomalaista modernia runoutta keskittymällä muun muassa poetiikan kysymyksiin, ihmisen ja luonnon väliseen suhteeseen ja omaelämäkerrallisuuteen. Tällä hetkellä hänen kiinnostuksen kohteenaan on kirjallisuuden ja tunteiden tutkimus, erityisesti surun ilmaiseminen runouden keinoin. Sipilä on tutkinut Antti Tuuria, Hannu Raittilaa, Aleksis Kiveä ja Pentti Haanpäätä. Häntä kiinnostavat erityisesti Raamatun ja kirjallisuuden väliset suhteet, samoin se, miten eri tavoin sota jatkuu kirjallisuudessa.

Oppiaineessa on lisäksi laaja joukko tutkijoita ja väitöskirjantekijöitä, joilla on omia tutkimusprojekteja. Käynnissä on lisäksi laajempia hankkeita. Oppiaine on yksi kolmesta osallisesta Suomen Akatemian konsortiohankkeessa The Literary in Life: Exploring the Boundaries between Literature and the Everyday (2015-2019). Helsingin ryhmä, jota johtaa Pirjo Lyytikäinen ja jonka tutkijoina toimivat Riikka Rossi, Anna Hollsten ja Elise Nykänen, tutkii kirjallisuuden kuvaamia ja tuottamia tunteita ja niiden suhdetta arkimaailmaamme. Ryhmä tarkastelee suomalaista kirjallisuutta osana kulttuuristen tunteiden ja tunneyhteisöjen pelikenttää yhdistämällä kognitiivista ja fenomenologista tunteiden tutkimusta ja kollektiivisten tunteiden tutkimusta. Jyrki Nummen johtama hanke Aleksis Kivi ja 1800-luvun suomalaisen runokielen synty sekä Aleksis Kiven kriittiset editiot -hanke tutkivat suomalaisen kirjallisuuden varhaisvaiheiden historiallisia, kielellisiä ja runousopillisia kysymyksiä. Kumpikin hanke on Suomalaisen Kirjallisuuden Seuran ja Kotimaisten kielten keskuksen kanssa yhteistyössä etenevä monivuotinen tutkimus- ja julkaisuprojekti, joka yhdistää tutkijoita maamme yliopistoista.

Dosentti Riikka Rossin johtamassa, Helsingin yliopiston rahoittamassa tutkimushankkeessa Realismin kirjalliset maailmat (2013-2017) tartutaan realismin monimuotoiseen käsitteeseen uusista affektiivisista ja kognitiivisista näkökulmista ja tarkastellaan realismin suhdetta toisiin lajeihin yhteistyössä kansainvälisten realismin ja naturalismin tutkijoiden kanssa. Hankkeen toimittama Avaimen realismi-erikoisnumero ilmestyi 1/2015, ja hankkeen tutkija Antti Ahmala väitteli 2016 autenttisuudesta Joel Lehtosen tuotannossa. Tekeillä on naturalismin ja dekadenssin pohjoisia muotoja käsittelevä kansainvälinen artikkelikokoelma Nordic Decadence. Projekti on mukana järjestämässä 2017 pidettävää End Games -konferenssia Tallinnan ja Helsingin yliopistoissa.

Helsingin kotimaisen opiskelijoilla on oma, aktiivisesti toimiva ainejärjestö Putkinotko, joka jakaa vuosittain Toisinkoinen-palkinnon (vrt. Helsingin Sanomien esikoiskirjapalkinto) ja julkaisee lehteä nimeltä Käkriäinen. 